\title{
Role of Oxides of Nitrogen in Tobacco-Specific Nitrosamine Formation in Flue-Cured Tobacco*
}

\author{
by \\ T.B. Nestor ${ }^{l}$, J.S. Gentry ${ }^{l}$, D.M. Peele ${ }^{2}$, M.G. Riddick ${ }^{l}$, B.T. Conner ${ }^{1}$, and M.E. Edwards ${ }^{2}$ \\ ${ }^{1}$ R.J. Reynolds Tobacco Company, Bowman Gray Technical Center, Winston-Salem, NC, 27102, USA \\ ${ }^{2}$ R.J. Reynolds Tobacco Company, Avoca Division, Merry Hill, NC, 27957, USA
}

\section{SUMMARY}

Tobacco is known to contain a class of nitrosamines known as tobacco-specific nitrosamines or TSNA. Nitrosation of naturally occurring tobacco alkaloids is commonly accepted as the mechanism of TSNA formation in tobacco. Because green and freshly harvested tobaccos are virtually free of TSNA, formation and accumulation of TSNA are generally considered to occur during the curing process. Most recent hypotheses have focused on microbial reduction of nitrate to nitrite and other oxides of nitrogen ( $\mathrm{NO}_{\mathrm{x}}$ compounds) that react with tobacco alkaloids to form TSNA during curing. This natural microbial process remains the prevalent hypothesis for TSNA formation in burley and other aircured tobaccos. However, a different mechanism for the formation of TSNA in flue-cured tobacco, independent of microbial activity, is documented in this paper.

It is common practice to flue-cure Virginia or blonde tobacco in bulk barns that incorporate forced air ventilation and temperature control. For the last thirty-five years, many modern bulk barns in North America generally have used liquid propane gas (LPG) with direct-fired burners that exhaust combustion gases directly into the barn where the tobacco is exposed to those gases. Our studies indicate that LPG combustion by-products in the exhaust stream, namely $\mathrm{NO}_{x}$, react with naturally occurring tobacco alkaloids to form TSNA. Heat exchange curing methods preclude exposure of the tobacco to combustion gases and by-products, thereby eliminating this significant source of TSNA formation, without degrading leaf quality or smoking character. Research findings from 1998 and 1999 are presented to demonstrate the role of $\mathrm{NO}_{\mathrm{x}}$ gases in TSNA formation and the significance of direct-fired curing as a primary source of TSNA formation in flue-cured tobacco. Also, data from an extensive barn conversion program in 2000, which resulted in a 94\% average reduction in TSNA levels in cured flue-cured leaf, are presented. [Beitr. Tabkakforsch. Int. 20 (2003) 467-475]

\section{ZUSAMMENFASSUNG}

Tabak enthält bekanntermaßen eine Gruppe von Nitrosaminen, die als tabakspezifische Nitrosamine oder TSNA bekannt sind. Die Nitrosierung natürlich vorkommender Tabakalkaloide gilt generell als der Mechanismus der TSNA Entstehung im Tabak. Da grüner und frisch geernteter Tabak fast keine TSNA enthält, wird allgemein angenommen, dass die Bildung und Ansammlung der TSNA während des Trocknungsprozesses stattfindet. Neueste Hypothesen beruhen auf einer mikrobiologischen Reduktion des Nitrats zu Nitrit und Stickstoffoxiden $\left(\mathrm{NO}_{\mathrm{x}}\right.$ Verbindungen), die mit Tabakalkaloiden reagieren und während der Trocknung TSNA bilden. Dieser natürliche mikrobiologische Prozess bleibt die vorherrschende Hypothese für die TSNA Entstehung in Burley Tabak und anderen luftgetrockneten Tabaken. In dieser Arbeit wird jedoch ein anderer Mechanismus für die Entstehung von TSNA in flue-cured Tabaken beschrieben, der unabhängig von mikrobiologischen Vorgängen ist.

Das Bulk Flue-curing in Trockenschuppen unter verstärkter Ventilation und kontrollierter Temperatur ist bei Virginia Tabak oder hellen Tabaken allgemein üblich. In den letzten 35 Jahren wurde in vielen modernen Trockenschuppen Nordamerikas flüssiges Propangas (LPG) mit direkt gefeuerten Brennöfen verwendet, wodurch die bei der Verbrennung entstehenden Gase direkt in den Trockenschuppen geleitet werden und der Tabak dann diesen Gasen ausgesetzt wird. Unsere Untersuchungen weisen darauf hin, dass die bei der Verbrennung von LPG entstehenden Nebenprodukte im entweichenden Strom, insbesondere $\mathrm{NO}_{\mathrm{x}}$, mit den natürlich vorkommenden Tabakalkaloiden reagieren und TSNA bilden. Auf einem Wärmeaustausch beruhende Trocknungsmethoden verhindern, dass der Tabak Verbrennungsgasen und Nebenprodukten ausgesetzt ist und eliminieren somit diese bedeutende Quelle der TSNA Bildung, ohne die Qualität des Blattes oder Rauches zu vermindern. Untersuchungsergebnisse aus den Jahren 1998 und 1999 
werden präsentiert, um die Rolle von $\mathrm{NO}_{\mathrm{x}}$ bei der Bildung von TSNA und die Bedeutung der Direkttrocknung mit Heißluft als Hauptquelle der TSNA Entstehung bei fluecured Tabaken aufzuzeigen. Daten eines umfangreichen Trockenschuppen-Umgestaltungsprogramms aus dem Jahre 2000, aus dem eine durchschnittliche Verringerung der TSNA Konzentrationen um $94 \%$ resultierte, werden ebenfalls präsentiert. [Beitr. Tabakforsch. Int. 20 (2003) 467-475]

\section{RESUME}

Il est connu que le tabac contient une classe de nitrosamines, connus sous le nom de nitrosamines spécifiques du tabac ou TSNA. La nitrosation des alcaloïdes du tabac présents naturellement est généralement considérée comme le mécanisme de formation des TSNA dans le tabac. Comme le tabac vert et fraîchement récolté est pratiquement dépourvu de TSNA, la formation et l' accumulation des TSNA sont généralement considérées comme apparaissant au cours du séchage. Les hypothèses les plus récentes se focalisent sur la réduction microbienne du nitrate en nitrite et autres oxydes d' azote (composés $\mathrm{NO}_{\mathrm{x}}$ ) qui réagissent avec les alcaloïdes de tabac pour former des TSNA au cours du séchage. Ce processus microbien naturel reste l' hypothèse la plus prédominante de la formation des TSNA dans le tabac Burley et d' autres tabacs séchés à l' air. Cependant, un mécanisme différent de formation des TSNA dans le tabac «flue-cured», indépendamment d' une activité microbienne, est présenté dans cette étude.

Le séchage «flue-cured» en bulk avec ventilation forcée et contrôle de la température est la pratique courante pour sécher le tabac Virginie ou les tabacs blonds. Au cours des 35 dernières années, plusieurs séchoirs bulk moderne en Amérique du Nord ont utilisé le gaz propane liquide (LPG) avec des brûleurs à flamme directe émettant les gaz de combustion directement dans le séchoir où le tabac est exposé à ces gaz. Nos études révèlent que des sous-produits dans le flux émanant formés par la combustion de LPG, notamment le $\mathrm{NO}_{\mathrm{x}}$, réagissent avec les alcaloïdes naturellement présents dans le tabac pour former des TSNA. Le séchage avec des échangeurs thermiques empêchent l' exposition du tabac au gaz de combustion et aux sousproduits, éliminant ainsi cette source significative de formation des TSNA, sans pour autant détériorer la qualité des feuilles ou les composants de la fumée. Des données de 1998 et 1999 sont présentées pour démontrer le rôle que jouent des gaz $\mathrm{NO}_{\mathrm{x}}$ dans la formation des TSNA et le rôle du séchage à flamme directe comme source primaire de la formation des TSNA dans les tabacs «flue-cured». De plus, les données d' un programme extensif de transformation des séchoirs en 2000 , montrent une réduction moyenne de 94\% des teneurs en TSNA dans les feuilles «flue-cured». [Beitr. Tabakforsch. Int. 20(2003) 467-475]

\section{INTRODUCTION}

For decades, nitrosamines have been a focus of considerable research for which references abound in the scientific literature. The presence of nitrosamines in cigarette smoke and their possible role in tobacco carcinogenesis were first postulated in the scientific literature in 1962 (1). Decades of research have provided no solid proof for concluding cause and effect relevancy of nitrosamines to chronic disease in smokers $(2,3,4,5,6)$ despite implied contentions to the contrary (7). Without such relevancy, the effect of reducing levels of nitrosamines in tobacco or tobacco smoke cannot be definitively asserted. However, responsible product stewardship advocates that technologies to reduce nitrosamine levels in tobacco be pursued and implemented as proven effective and commercially practicable.

Extensive research by many investigators since the 1970's reported the presence of as many as 35 nitrosamines in cigarette smoke. A subset of those nitrosamines was considered to be specific to tobacco, resulting from nitrosation of endogenous tobacco alkaloids. Today, eight tobacco-specific nitrosamines (TSNA) have been identified and seven have been reported as present in cigarette smoke $(7,8,9)$. The breadth of TSNA investigations over the last three decades spans a wide range of topics including formation and accumulation of TSNA in tobacco $(10,11,12)$, quantitative analyses of TSNA in tobacco and tobacco smoke $(2,3)$, epidemiology, animal studies, and possible chronic health effects of TSNA in smokers $(13,14,15,16)$.

Nitrosation of naturally occurring tobacco alkaloids is commonly accepted as the mechanism of TSNA formation in cured tobacco. $\mathrm{N}$-nitrosonornicotine $(\mathrm{NNN}), 4-(\mathrm{N}$ methylnitrosamino)-1-(3-pyridyl)-1-butanone (NNK), $\mathrm{N}$ nitrosoanabasine (NAB), and $N$-nitrosoanatabine (NAT) are the more prevalent TSNA in tobacco and tobacco smoke and, thus, receive the most attention in scientific literature and discussion. NNK is considered to be derived from nicotine, NNN from both nicotine and nornicotine, NAB from anabasine, and NAT from anatabine. While all four TSNA are generally found in flue-cured and burley tobacco, NNK is typically the most prevalent in flue-cured tobacco cured in direct-fired barns, while NNN is most prevalent in aircured burley tobacco. TSNA are generally absent or below quantitative limits in Oriental tobacco.

In 1998, HECHT summarized the work of many authors on the effects of fertilization rates, plant maturity at harvest, genotype, alkaloid level, and tobacco storage on the levels of TSNA in burley tobacco (7). However, prior to 1999 little work had been reported on TSNA formation in flue-cured tobacco. It is generally agreed that minimal-to-no TSNA are present in green Virginia or burley tobacco. TSNA formation and accumulation are considered to occur post-harvest and most predominantly during curing $(7,17,18,19,20)$. Most recent hypotheses on TSNA formation focused on microbial reduction of nitrate to nitrite and other oxides of nitrogen $\left(\mathrm{NO}_{\mathrm{x}}\right.$ compounds) that react with tobacco alkaloids to form TSNA during the curing process (7). The natural microbial process remains the prevalent hypothesis on TSNA formation in burley tobacco. However, direct-fired curing presents a second, and significantly more important, source of nitrosating agent in the flue-curing process. Precedent for this hypothesis exists in the literature from the milk and beer industries $(21,22)$. STARTIN reported that as early as the late 1970 's, the presence of nitrosamines in beers "was the result of reaction of amines formed during germination with nitrogenous products formed in kilning when direct-firing with natural gas was used as the heat source" (22). 


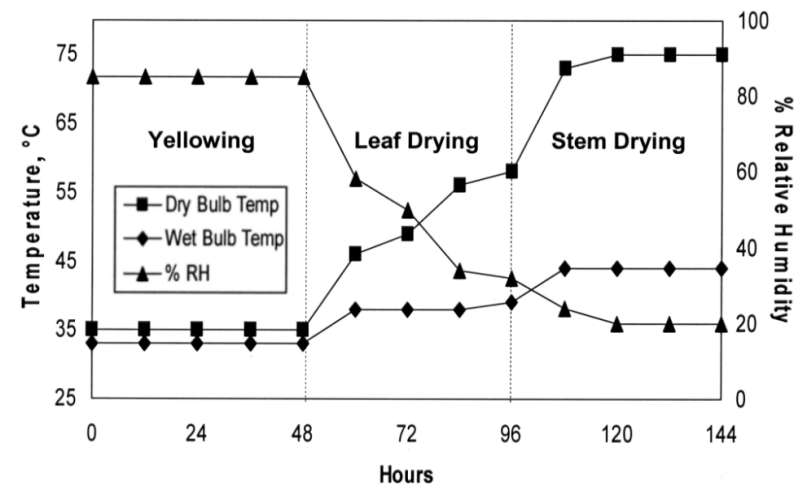

Figure 1. Typical schedule for flue-curing tobacco. Graphical depiction of typical flue-curing schedule in terms of relative humidity $(\mathrm{RH})$ and wet/dry bulb temperatures.

The objectives of this research were to demonstrate the importance of LPG combustion by-products, namely $\mathrm{NO}_{\mathrm{x}}$, on TSNA formation in flue-cured tobacco and the relevance of that finding to direct-fired vs. heat-exchanged methods of flue-curing tobacco.

\section{Flue-curing of tobacco}

The flue-curing process typically takes from five to eight days and involves three sequential steps of yellowing, leaf drying, and stem drying (23). Figure 1 graphically depicts a typical flue-curing schedule in terms of relative humidity and wet/dry bulb temperatures. Generally, the yellowing phase requires 36 to $72 \mathrm{~h}$ in which dry bulb temperature and relative humidity are maintained at approximately $35{ }^{\circ} \mathrm{C}$ and $85 \%$, respectively. During the next 48 -h leafdrying phase, temperature is slowly increased from 35 to $60{ }^{\circ} \mathrm{C}$, and relative humidity is decreased from $85 \%$ to approximately $35 \%$. The last 48 -h stem-drying phase is carried out at $75{ }^{\circ} \mathrm{C}$, following a gradual ramp from $60{ }^{\circ} \mathrm{C}$, and relative humidity is allowed to drop to approximately $18 \%$. Finally, the tobacco is allowed to reorder (equilibrate to proper handling moisture) for post-cure processing. The quality of flue-cured tobacco is highly dependent on temperature and humidity control within the barn to allow for natural biochemical changes to occur while drying the leaf and stem.

In North America today, it is common practice to flue-cure Virginia or blonde tobacco in commercial bulk barns that incorporate forced air ventilation and temperature control. During the 1960's mechanization, the need for labor savings, and consolidation of smaller family farms resulted in the replacement of farmer-built 'stick barns' with heatexchanged flue systems to more energy efficient bulk barns using direct-fired liquid propane gas (LPG) burners. These LPG direct-fired burner systems exhaust combustion gases and combustion by-products directly into the barn where contact is made with the curing tobacco. The vast majority of commercial direct-fired burners are generally capable of 100,800 to $151,200 \mathrm{~kg}$-cal $(400,000$ to $600,000 \mathrm{BTU})$ per hour, resulting in an LPG consumption rate of approximately 570 to $1140 \mathrm{~L}$ (150 to 300 gal) per cure. Based on US Environmental Protection Agency emission factors, approximately $1.7 \mathrm{~kg}$ of $\mathrm{NO}_{\mathrm{x}}$ are produced per $1000 \mathrm{~L}$ of
LPG combusted (14 lb NO $/ 1000$ gal LPG) (24). Consequently, the net effect is that the tobacco in LPG directfired bulk barns is exposed to approximately 1.0 to $1.9 \mathrm{~kg}$ ( 2 to $4 \mathrm{lb}$ ) of $\mathrm{NO}_{\mathrm{x}}$ per cure.

In stark contrast to direct-fired curing, heat-exchange burner configurations completely vent combustion gases and combustion by-products to the external atmosphere rather than into the barn. The heat-exchange process precludes exposure of the tobacco to LPG combustion byproducts, particularly $\mathrm{NO}_{x}$, thereby eliminating an important source of nitrosating agent for TSNA formation.

\section{MATERIALS AND METHODS}

In 1998 and 1999, laboratory and curing experiments were conducted at the AVOCA research facility located in Merry Hill, NC. Additional curing research in commercial bulk barns equipped with heat-exchangers was carried out at five farms located in eastern North Carolina in 1999.

\section{a) Laboratory experiments with tobacco alkaloids and $\mathrm{NO}_{x}$}

A series of laboratory experiments was conducted in which neat alkaloids were exposed to nitric oxide (NO) gas. Neat standards of nicotine (nicotine salicylate, Catalog no. 5270, Pfaltz \& Bauer, Waterbury, CT) and nornicotine (Catalog no. N3018, Sigma, St. Louis, MO) were diluted with isopropyl alcohol to achieve $6.2 \%$ and $0.25 \%$ solution concentrations, respectively. Whatman (Maidstone, England) no. 3 filter paper ( $90 \mathrm{~mm}$ circles) was chosen as the substrate to which the neat alkaloids were applied. The alkaloid solutions were applied to the filter paper in sufficient quantity to achieve the desired alkaloid concentration by weight on the filter paper. The isopropyl alcohol was evaporated at room temperature before the treated papers were exposed to nitric oxide gas. The nitric oxide gas was purchased from Praxair Distribution, Inc. (Bethlehem, PA) and described as 99.5\% nitric oxide, Product Number 2.5-K, Batch Number BP101697NX with certificate of analysis dated September 11, 1998.

To expose the treated filter papers to $\mathrm{NO}_{\mathrm{x}}$ gas, the corner of a $12 \times 12$ inch $(30.5 \times 30.5 \mathrm{~cm})$ Dow Chemical saran wrap film bag with sealed exit tube (Anspec Company, Ann Arbor, MI) or $8 \times 12$ inch $(20.3 \times 30.5 \mathrm{~cm})$ Fidus Instrument Corp. sample bag with sealed exit tube was cut and a treated paper was inserted. The bag was then resealed using an electrical heating impulse sealer and filled with one liter of air to allow proper circulation around the treated filter paper. The bag was checked for leaks, and if none were detected, nitric oxide gas was injected into the sample bag via the attached sampling tube. The formation of a reddishbrown gas indicated the presence of other reaction species such as $\mathrm{NO}_{2}$. A range of $\mathrm{NO}_{\mathrm{x}}$ exposures was injected using $250 \mu \mathrm{L}, 1$, or $5 \mathrm{~mL}$ Hamilton Gastight syringes. The sample bag was gently shaken to insure adequate mixing of $\mathrm{NO}_{\mathrm{x}}$. After one hour exposure, the bag was cut open and the filter paper was prepared for TSNA analysis.

To analyze for TSNA, the filter paper sample was placed into a $250 \mathrm{~mL}$ Erlenmeyer flask. One hundred $\mathrm{mL}$ of methylene chloride (HPLC grade, Burdick \& Jackson, Muskegon, MI) was added and the flask sealed with a 
glass stopper. The sample was hand shaken periodically and allowed to extract for 30 minutes. The sample extract was poured into a $300 \mathrm{~mL}$ Zymark sampling tube with a $0.5 \mathrm{~mL}$ stem (Zymark Corp, Hopkington, MA). The flask was rinsed with $10 \mathrm{~mL}$ methylene chloride and also poured into the sampling tube. The sample tube containing the extract was placed in a TurboVap Concentrator (Zymark Corp, Hopkington, MA), whose water bath was preheated to $38{ }^{\circ} \mathrm{C}$. The sampling tube was removed from the TurboVap after the sample extract was concentrated to approximately $2 \mathrm{~mL}$. The walls of the sample tube were rinsed with approximately $3 \mathrm{~mL}$ methylene chloride to achieve a final volume of $5 \mathrm{~mL}$. The sample extract was not disturbed for $5 \mathrm{~min}$ to allow any paper fibers present to settle within the sample tube. The top portion of the sample extract was pipetted into an autosampler vial, sealed with a thin Teflon septum, and analyzed for TSNA by gas chromatography-thermal energy analyzer (GCTEA) in accordance with the method of RISNER and WENDELBOE (25).

\section{b) Curing experiments in $R \& D$ barns}

A series of curing experiments was conducted in four small, 8-rack research \& development (R\&D) barns capable of holding approximately $450 \mathrm{~kg}$ of green tobacco (or $65 \mathrm{~kg}$ of cured leaf). Two of these 8-rack R\&D barns were fitted with 20 kilowatt electrical resistance-heating units of 17,140 kg-cal (68,000 BTU) per hour capability. These electric barns serve to represent heat-exchange curing structures in that convective and radiant heating is employed, and the introduction of exhaust combustion gases into these barns is avoided. Two similar barns were equipped with LPG direct-fired burner units of $18,900 \mathrm{~kg}$ cal $(75,000$ BTU) per hour capability. Fans in each barn were sized to provide volume-adjusted air exchanges comparable to the wide range of commercial bulk barns. The leaves to be cured were from mid- to upper-stalk Virginia tobacco (cv. K326), and curing schedules were generally in accordance with that described in Figure 1. In some experiments nitric oxide gas, previously described, was metered into these small barns. Tobacco samples were collected from curing structures to appropriately represent the entire barn in terms of box or rack locations. All TSNA analyses in tobacco were performed as described above (25).

\section{c) Curing experiments in commercial bulk barns equipped with heat-exchangers}

Twenty-seven commercial bulk barns were converted from direct-fired to heat-exchange curing. The existing furnace comprised of fan, motor, burner, and intake damper was removed and replaced with a Vencon Varsos heat-exchange furnace (Model Ventobacco VCU, Rentis, Piraeus, Greece). The existing intake dampers were disconnected and replaced with a single motorized intake unit. Also, Vencon Varsos curing computers (VK-981) replaced the existing Reliance thermostats. Several manufacturers of commercial bulk barns, including Long, Powell, and Taylor, were represented in these conversions. All farms used either LPG or natural gas fuel. Curing schedules were generally in accordance with that described in Figure 1. Tobacco was cured throughout the curing season and included low-, mid-, and upperstalk Virginia tobacco.

As in the previous experiments, samples were collected from curing structures to appropriately represent the entire barn in terms of box or rack location. All TSNA analyses in tobacco were performed as described previously (25).

\section{RESULTS AND DISCUSSION}

a) Laboratory experiments with tobacco alkaloids and $N O_{x}$

In a series of laboratory experiments neat alkaloids were exposed to $\mathrm{NO}_{\mathrm{x}}$ to isolate nitrosation from any microbial or enzymatic interference. First, extraction recovery assessments were performed by applying known amounts of TSNA standards (NNN, NAT, NNK) onto a filter paper. The filter paper was extracted using methylene chloride and analyzed for TSNA. Average extraction recovery efficiencies for five replicates were found to be $103 \% \pm 5.6$ for NNN, $99 \% \pm 5.8$ for NAT, and $107 \% \pm 4.1$ for NNK. In addition, tests were performed to ensure the nicotine solution ingredients (nicotine or isopropyl alcohol) did not interfere with the analysis of TSNA. Two filter papers were treated with the nicotine solution to achieve $3.0 \%$ nicotine by weight and two filter papers with isopropyl alcohol. One filter paper of each was analyzed for TSNA without any $\mathrm{NO}_{\mathrm{x}}$ exposure and served as controls. The other two papers were exposed to a $100 \%$ atmosphere of nitric oxide gas. No TSNA were detected on the filter papers not exposed to $\mathrm{NO}_{\mathrm{x}}$ (controls). In addition, the isopropyl alcohol treated filter paper that was exposed to $\mathrm{NO}_{\mathrm{x}}$ did not show any TSNA formation. TSNA were only found on the filter paper treated with the nicotine solution and exposed to $\mathrm{NO}_{\mathrm{x}}$. These results confirmed good extraction recovery efficiencies and the absence of experimental interferences. Initial experiments simply exposed filter papers treated with a nicotine or nornicotine solution to an atmosphere of $100 \%$ nitric oxide gas. Analysis of the exposed papers found NNN and NNK on the nicotine treated papers and NNN on the nornicotine treated papers. These cursory experiments confirmed the hypothesis that alkaloids in the presence of $\mathrm{NO}_{\mathrm{x}}$ react to form TSNA.

A modern LPG direct-fired bulk barn holds 800 to $1100 \mathrm{~kg}$ (1800 to $2500 \mathrm{lbs}$ ) of cured tobacco and produces 1.0 to 1.9 $\mathrm{kg}(2$ to $4 \mathrm{lb})$ of $\mathrm{NO}_{\mathrm{x}}$. Assuming a density of $1.35 \mathrm{~g} / \mathrm{L}$ for $\mathrm{NO}_{\mathrm{x}}$, it was determined that a typical exposure was approximately 600 to $1600 \mu \mathrm{L}$ of $\mathrm{NO}_{x}$ per gram of tobacco.

To develop dose response curves, filter papers were treated with the nicotine solution to achieve $3.0 \%$ (equivalent to 35 mg per filter) nicotine by weight and then exposed to $\mathrm{NO}_{x}$ levels ranging from 250 to $2000 \mu \mathrm{L}$ and analyzed for TSNA content. A dose response was observed and is illustrated in Figure 2. NNN and NNK were detected for all $\mathrm{NO}_{x}$ exposure levels and increased significantly as $\mathrm{NO}_{x}$ exposure increased.

Following the dose response observation of $\mathrm{NO}_{\mathrm{x}}$ gas at constant nicotine, exposure of $\mathrm{NO}_{\mathrm{x}}$ to various nicotine levels was then investigated. Filter papers were treated with the nicotine solution to achieve three nicotine levels $(1.5 \%$ or $17.5 \mathrm{mg}, 3.0 \%$ or $35 \mathrm{mg}$, and $4.5 \%$ or $52.5 \mathrm{mg}$ ) and 


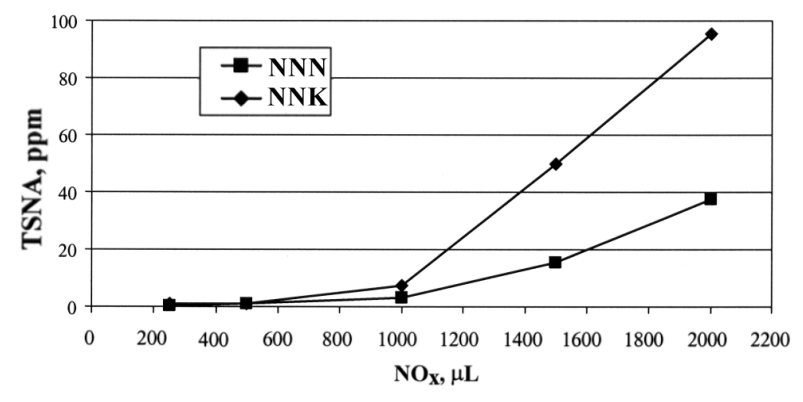

Figure 2. Dosage experiment with $\mathrm{NO}_{\mathbf{x}}$ gas and nicotine. Filter papers treated with $3.0 \%$ nicotine by weight. Treated papers were exposed to $250,500,1000,1500$, and $2000 \mu \mathrm{L} \mathrm{NO}$ levels and analyzed for TSNA content.

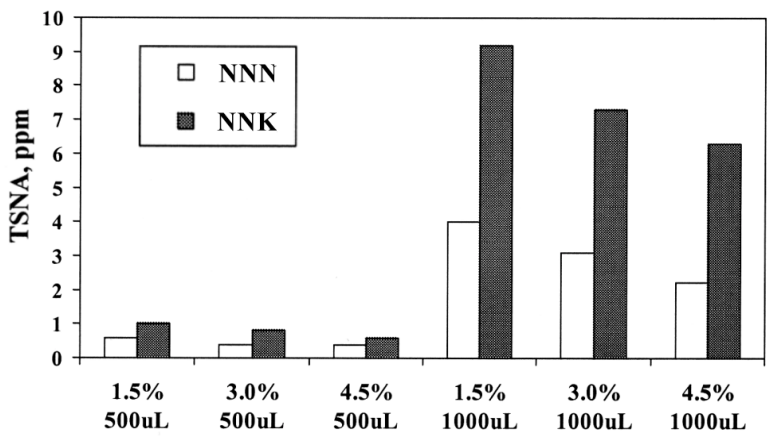

Figure 3. Variation of nicotine with $\mathrm{NO}_{\mathrm{x}}$ gas. Filter papers treated with $1.5,3.0$, and $4.5 \%$ nicotine by weight. Treated papers were exposed to 500 and $1000 \mu \mathrm{L} \mathrm{NO}$ levels and analyzed for TSNA content.

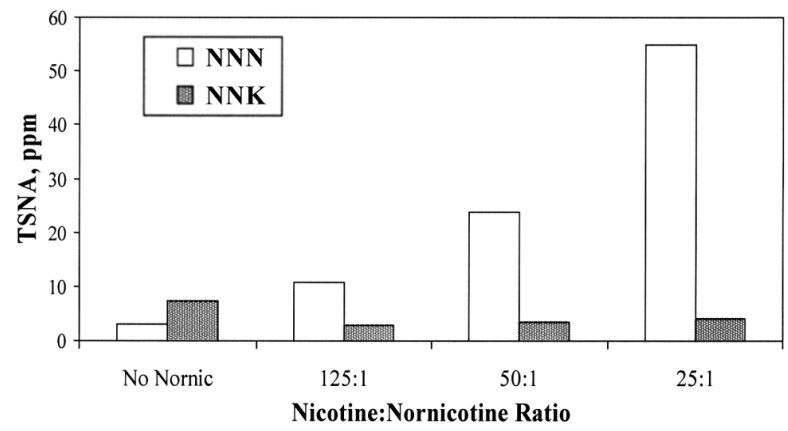

Figure 4. Effect of nicotine to nornicotine ratio. Filter papers treated with varying nicotine to nornicotine ratios (nicotine only, 125:1, 50:1, and 25:1; with nicotine kept constant at $35 \mathrm{mg}$ per filter). Treated papers were exposed to $1000 \mu \mathrm{L} \mathrm{NO}_{x}$ and analyzed for TSNA content.

exposed to either 500 or $1000 \mu \mathrm{L}$ of $\mathrm{NO}_{\mathrm{x}}$. A dose response for TSNA formation was not found for nicotine content, as illustrated in Figure 3. TSNA results for the three nicotine levels exposed to $500 \mu \mathrm{L} \mathrm{NO}_{x}$ were not significantly different from each other; however, they did trend down slightly as nicotine increased. Likewise, TSNA results for the three nicotine levels exposed to $1000 \mu \mathrm{L} \mathrm{NO}_{\mathrm{x}}$ were not significantly different from each other and showed a similar trend. The TSNA results of the nicotine treated papers exposed to $1000 \mu \mathrm{L} \mathrm{NO}_{\mathrm{x}}$ were significantly higher in NNN
Table 1. Effect of burner configuration on TSNA level; TSNA reported as the summation of NNN, NNK, and NAT.

\begin{tabular}{lcc|c}
\hline Barn type & $\begin{array}{c}\text { Burner } \\
\text { configuration }\end{array}$ & $\begin{array}{c}\text { TSNA in } \\
\text { tobacco (ppm) }\end{array}$ & $\begin{array}{c}\mathrm{NO}_{x} \text { from } \\
\text { combust. (kg) }\end{array}$ \\
\hline R\&D Electrical & $\begin{array}{c}\text { Heat- } \\
\text { exchange }\end{array}$ & $\mathrm{BLQ}^{\mathrm{a}}$ & 0 \\
R\&D LPG & $\begin{array}{c}\text { Direct-fired } \\
\text { Commercial LPG }\end{array}$ & 2 & 0.18 \\
& Direct-fired & 13 & 1.15 \\
\hline
\end{tabular}

${ }^{\mathrm{a}} \mathrm{BLQ}=$ Below level of quantification.

(6-7 times) and NNK (9-10 times) levels than similarly treated papers exposed to $500 \mu \mathrm{L} \mathrm{NO}_{\mathrm{x}}$. These data indicate that the magnitude of TSNA formation is dependent on $\mathrm{NO}_{\mathrm{x}}$ exposure level and not nicotine content.

Although the previous experiments with single alkaloids demonstrated compelling evidence that $\mathrm{NO}_{\mathrm{x}}$ was a strong nitrosating agent, another experiment was conducted to determine if combinations of alkaloids would behave similarly. A series of nicotine to nornicotine ratios (25:1, 50:1, and 125:1) was applied to filter papers to represent possible ratios found in tobacco (26). Papers were treated with the nicotine solution to achieve $3 \%(35 \mathrm{mg})$ nicotine by weight and then nornicotine was added $(1.4,0.70$, and 0.28 $\mathrm{mg}$ ) to achieve the desired ratio. Treated papers were exposed to $1000 \mu \mathrm{L} \mathrm{NO}_{\mathrm{x}}$ and analyzed for TSNA. The TSNA results, illustrated in Figure 4 , indicate that at constant nicotine the amount of NNN increased significantly as the level of nornicotine increased. Also, the NNK level was lower for all papers that were treated with nornicotine. This may be explained by the fact that the reaction of secondary amine alkaloids with a nitrosating species is faster than that of the tertiary amine nicotine (11).

While the treatment of filter papers with neat alkaloids may not completely represent a tobacco leaf, these laboratory experiments are able to demonstrate the mechanistic role that oxides of nitrogen have in TSNA formation.

\section{b) Curing experiments in $R \& D$ barns}

In an initial experiment, primed tobacco was loaded into an 8-rack electrical R\&D barn, an 8-rack LPG direct-fired R\&D barn, and a direct-fired commercial barn. At the end of cure, tobacco from each barn was sampled and analyzed for TSNA levels. The results are summarized in Table 1. The electrical barn, absent an external nitrosating agent from LPG combustion, demonstrated TSNA levels below quantification. Both the R\&D and commercial direct-fired barns showed measurable levels of TSNA. Approximate emissions of $\mathrm{NO}_{\mathrm{x}}$ from the direct-fired barns were calculated from recorded LPG consumption and are also given in Table 1.

Following the observation above on heat-exchange vs. direct-fired configurations, the effect of exogenous nitrosating agents, which are expected to be present in the combustion stream of direct-fired curing barns, was investigated. Tobacco was loaded into each of the four 8rack R\&D barns. Two of the barns were electrically heated while the other two were LPG direct-fired. The tobacco was 
Table 2. Effect of exogenous $\mathrm{NO}_{\mathrm{x}}$ on TSNA levels in tobacco ${ }^{\text {a }}$

\begin{tabular}{|c|c|c|c|}
\hline Barn type & Mean ${ }^{b, c}$ & Std. dev. ${ }^{c}$ & Range \\
\hline \multicolumn{4}{|l|}{ Electric (control) } \\
\hline NNN & 0.40 & 0.11 & $0.26-0.50$ \\
\hline NAT & 0.26 & 0.29 & BLQ-0.51 \\
\hline NAB & BLQ & $\mathrm{n} / \mathrm{a}$ & $\mathrm{n} / \mathrm{a}$ \\
\hline NNK & 0.29 & 0.38 & BLQ-0.79 \\
\hline Total TSNA & 0.95 & 0.61 & $0.36-1.56$ \\
\hline \multicolumn{4}{|c|}{ Electric (1.8 $\mathrm{kg} \mathrm{NO}_{x}$ added) } \\
\hline NNN & 87.8 & 25.0 & $57.2-112.2$ \\
\hline NAT & 71.1 & 15.9 & $49.2-86.6$ \\
\hline NAB & 6.5 & 1.4 & $4.6-7.6$ \\
\hline NNK & 8.6 & 2.2 & $6.0-11.2$ \\
\hline Total TSNA & 174.0 & 41.6 & $117.0-208.9$ \\
\hline \multicolumn{4}{|c|}{ LPG Direct-fired (control) } \\
\hline NNN & 1.26 & 0.23 & $1.03-1.53$ \\
\hline NAT & 0.97 & 0.83 & $0.25-1.79$ \\
\hline NAB & 0.40 & 0.33 & BLQ-0.75 \\
\hline NNK & 2.03 & 0.35 & $1.77-2.52$ \\
\hline Total TSNA & 4.66 & 1.55 & $3.20-6.43$ \\
\hline \multicolumn{4}{|c|}{ LPG Direct-fired (1.8 kg NO ${ }_{x}$ added) } \\
\hline NNN & 46.2 & 31.4 & $25.2-92.9$ \\
\hline NAT & 49.3 & 29.5 & $28.2-92.9$ \\
\hline NAB & 4.2 & 1.7 & $2.4-5.7$ \\
\hline NNK & 7.6 & 2.3 & $5.7-10.7$ \\
\hline Total TSNA & 107.3 & 63.7 & $66.7-202.2$ \\
\hline
\end{tabular}

${ }^{\text {a }}$ Abbreviations: $\mathrm{BLQ}=$ below level of quantification; $\mathrm{n} / \mathrm{a}=$ not applicable.

${ }^{\mathrm{b}}$ TSNA averages reported in $\mathrm{ppm}(n=4)$.

${ }^{\mathrm{C}}$ Samples found to be below the limit of quantification were assigned a value of $0.0 \mathrm{ppm}$.

yellowed for $48 \mathrm{~h}$ per a typical flue-curing schedule. Into one electrical and one LPG direct-fired barn, $1.8 \mathrm{~kg}(4 \mathrm{lb})$ of $\mathrm{NO}_{\mathrm{x}}$ gas was introduced during the last $24 \mathrm{~h}$ of the yellowing period. The remaining electrical and LPG directfired barns were operated as control barns not receiving any $\mathrm{NO}_{\mathrm{x}}$ treatment. The tobacco from each barn was sampled at the end of cure and analyzed for TSNA. The data, summarized in Table 2, show that the TSNA levels in tobacco from the LPG direct-fired control barn are significantly higher than from the electric control barn. Furthermore, and more importantly, the introduction of exogenous $\mathrm{NO}_{x}$ substantially increased TSNA in the tobacco, regardless of barn type

Given the significant increase in TSNA levels observed upon the introduction of exogenous $\mathrm{NO}_{x}$, it was reasonable to expect a dose-related response of TSNA to $\mathrm{NO}_{x}$ exposure. Tobacco was loaded into each of two electric $\mathrm{R} \& \mathrm{D}$ barns where no combustion source of $\mathrm{NO}_{\mathrm{x}}$ was present. As in the previous experiment, the tobacco was yellowed for $48 \mathrm{~h}$ and a quantity of $\mathrm{NO}_{\mathrm{x}}$ was introduced into each barn during the last $24 \mathrm{~h}$ of the yellowing period. One barn received a $0.45 \mathrm{~kg}(1 \mathrm{lb}) \mathrm{NO}_{\mathrm{x}}$ treatment while the other barn received a $1.8 \mathrm{~kg}(4 \mathrm{lb}) \mathrm{NO}_{x}$ treatment. The tobacco was sampled prior to the cure, just prior to any $\mathrm{NO}_{\mathrm{x}}$ treatment $(24 \mathrm{~h})$, and subsequently at

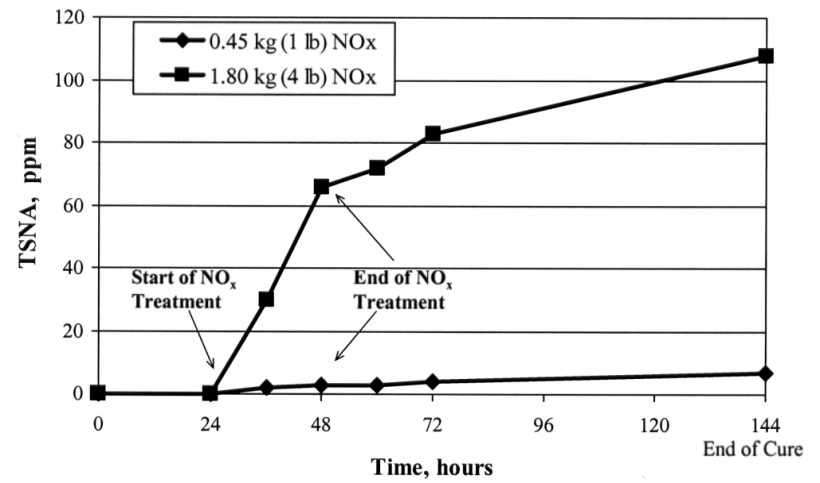

Figure 5. Dose effect of $\mathrm{NO}_{\mathrm{x}}$ gas on TSNA in tobacco. Experiment was conducted with 1998 flue-cured tobacco from eastern North Carolina. TSNA data expressed are the summation of NNN, NNK, and NAT. $\mathrm{NO}_{x}$ introduced $24 \mathrm{~h}$ into cure and discontinued at the 48-h point.

12-h intervals for the next $48 \mathrm{~h}$. Finally, the tobacco was sampled at the end of cure. TSNA in the tobacco were determined for each sampling interval on a dry weight basis and are illustrated in Figure 5. As expected, a significant dose response was observed. The $1.8 \mathrm{~kg}$ exogenous $\mathrm{NO}_{\mathrm{x}}$ treatment resulted in TSNA levels at least an order of magnitude higher than those observed for the $0.45 \mathrm{~kg} \mathrm{NO}_{x}$ treatment. In addition to demonstrating a significant dose response, these data also show TSNA levels increased rapidly during the $24 \mathrm{~h}$ of $\mathrm{NO}_{\mathrm{x}}$ treatment and continued to increase, albeit at a slower rate, over the life of the cure. Two possible explanations for the continuing TSNA formation may be the conversion of already nitrosated intermediary compounds or that $\mathrm{NO}_{\mathrm{x}}$ is absorbed or adsorbed by the leaf and continues to react with natural alkaloids to form TSNA.

\section{c) Curing experiments in commercial bulk barns equipped with heat-exchange systems}

In order to augment the controlled experiments described above, a number of commercially producing farms, representing varied agronomic, harvesting, and curing practices, were sampled in 1998 to compare direct-fired barns to heat-exchange barns. Table 3 summarizes the TSNA levels found for the various barns sampled. The data demonstrate that the TSNA levels for each heat-exchange barn configuration are significantly lower than observed for LPG direct-fired barns.

Given the results from the varying commercial heat-exchange barns and experiments conducted in the small $\mathrm{R} \& \mathrm{D}$ barns, a pilot barn conversion program was conducted in 1999. Tobacco cured in commercial bulk barns converted to heat-exchange curing was analyzed for TSNA levels and compared to tobacco cured in directfired bulk barns.

A total of 534 tobacco samples was taken throughout the curing season from the heat-exchange barns and compared to 110 similarly collected direct-fired samples. The data, summarized in Table 4, show a 90\% reduction in total TSNA levels in tobacco from the heat-exchange barns compared to tobacco from direct-fired barns. NNN, NAT, and NNK were reduced $89 \%, 87 \%$, and $93 \%$, respectively. 
Table 3. TSNA sampling from various commercial barns in 1998; TSNA reported in ppm.

\begin{tabular}{|c|c|c|c|c|}
\hline Barn type/fuel & Burner type & Mean $^{b}$ & Std. dev. ${ }^{b}$ & Range \\
\hline Stick/Wood & Flues & $(n=6)$ & & \\
\hline NNN & & 0.12 & 0.18 & BLQ-0.4 \\
\hline NAT & & 0.13 & 0.21 & BLQ-0.4 \\
\hline NAB & & BLQ & $\mathrm{n} / \mathrm{a}$ & $\mathrm{n} / \mathrm{a}$ \\
\hline NNK & & BLQ & $\mathrm{n} / \mathrm{a}$ & $\mathrm{n} / \mathrm{a}$ \\
\hline Total TSNA & & 0.25 & 0.39 & BLQ-0.8 \\
\hline Bulk/Diesel & $\begin{array}{c}\text { Heat- } \\
\text { exchange }\end{array}$ & $(n=27)$ & & \\
\hline NNN & & 0.19 & 0.21 & BLQ-0.7 \\
\hline NAT & & 0.26 & 0.23 & BLQ-0.7 \\
\hline NAB & & $B L Q$ & $\mathrm{n} / \mathrm{a}$ & $\mathrm{n} / \mathrm{a}$ \\
\hline NNK & & 0.21 & 0.36 & BLQ-1.2 \\
\hline Total TSNA & & 0.66 & 0.68 & BLQ-2.9 \\
\hline Bulk/LPG ${ }^{c}$ & $\begin{array}{c}\text { Heat- } \\
\text { exchange }\end{array}$ & $(n=23)$ & & \\
\hline NNN & & BLQ & $\mathrm{n} / \mathrm{a}$ & $\mathrm{n} / \mathrm{a}$ \\
\hline NAT & & BLQ & $\mathrm{n} / \mathrm{a}$ & $\mathrm{n} / \mathrm{a}$ \\
\hline NAB & & $B L Q$ & $\mathrm{n} / \mathrm{a}$ & $\mathrm{n} / \mathrm{a}$ \\
\hline NNK & & $B L Q$ & $\mathrm{n} / \mathrm{a}$ & $\mathrm{n} / \mathrm{a}$ \\
\hline Total TSNA & & BLQ & $\mathrm{n} / \mathrm{a}$ & $\mathrm{n} / \mathrm{a}$ \\
\hline Stick/LPG & Direct-fired & $(n=1)$ & & \\
\hline NNN & & 1.0 & $\mathrm{n} / \mathrm{a}$ & $\mathrm{n} / \mathrm{a}$ \\
\hline NAT & & 1.6 & $\mathrm{n} / \mathrm{a}$ & $\mathrm{n} / \mathrm{a}$ \\
\hline NAB & & 0.9 & $\mathrm{n} / \mathrm{a}$ & $\mathrm{n} / \mathrm{a}$ \\
\hline NNK & & 2.4 & $\mathrm{n} / \mathrm{a}$ & $\mathrm{n} / \mathrm{a}$ \\
\hline Total TSNA & & 5.9 & $n / a$ & $n / a$ \\
\hline Bulk/LPG & Direct-fired & $(n=43)$ & & \\
\hline NNN & & 2.7 & 1.4 & $1.2-7.7$ \\
\hline NAT & & 3.2 & 1.2 & $0.8-6.9$ \\
\hline NAB & & 1.2 & 0.6 & BLQ-2.9 \\
\hline NNK & & 4.0 & 1.7 & $1.1-7.6$ \\
\hline Total TSNA & & 11.1 & 4.0 & 3.3-19.9 \\
\hline
\end{tabular}

${ }^{\text {a }}$ Abbreviations: $B L Q=$ below level of quantification; $n / a=$ not applicable.

b Samples found to be below the limit of quantification were assigned a value of $0.0 \mathrm{ppm}$.

c LPG heat-exchange samples were obtained from Turkey.

Two-hundred and four (38\%) of the tobacco samples taken from the heat-exchange curing barns were below the level of quantification (BLQ), whereas no samples from directfired barns were BLQ. For the purpose of statistical analysis, BLQ samples were assigned a level of $0.0 \mathrm{ppm}$.

\section{RJR 2000 Barn Conversion Program}

With the information obtained from the research described above, R.J. Reynolds Tobacco Company (RJR) announced in December 1999 its intention to begin using US heat-exchange flue-cured tobacco as soon as practical. In order to obtain sufficient quantities of domestically grown, low TSNA tobacco, RJR began a program to assist growers with the cost of converting their existing bulk barns to heatexchange units. Over 1000 barns, representing all five fluecured tobacco growing states, were retro-fitted with new heat-exchange burners and accompanying forced air venti-
Table 4. TSNA levels in tobacco cured on commercial farms for 1999 by burner type. Averages are reported in ppm for the entire curing season (534 heat-exchange and 110 direct-fired tobacco samples).

\begin{tabular}{l|c|c|c}
\hline TSNA & $\begin{array}{c}\text { Heat-exchange } \\
\text { Mean }^{\mathrm{a}} \pm \text { std. dev. }\end{array}$ & $\begin{array}{c}\text { Direct-fired } \\
\text { Mean } \pm \text { std. dev. }\end{array}$ & Reduction \\
\hline NNN & $0.19 \pm 0.36$ & $1.74 \pm 0.85$ & $\mathbf{8 9 \%}$ \\
NAT & $0.32 \pm 0.56$ & $2.38 \pm 1.11$ & $\mathbf{8 7 \%}$ \\
NNK & $0.21 \pm 0.49$ & $2.82 \pm 1.51$ & $\mathbf{9 3} \%$ \\
Total TSNA & $0.72 \pm 1.31$ & $6.93 \pm 3.14$ & $\mathbf{9 0 \%}$ \\
\hline
\end{tabular}

a Samples found to be below the limit of quantification were assigned a value of $0.0 \mathrm{ppm}$.

Table 5. TSNA results from RJR 2000 Barn Conversion Program. Averages are reported in ppm for the entire curing season (2094 heat-exchange and 110 direct-fired tobacco samples).

\begin{tabular}{l|c|c|c}
\hline TSNA & $\begin{array}{c}\text { Heat-exchange } \\
\text { Mean }^{\mathrm{a}} \pm \text { std. dev. }^{\mathrm{a}}\end{array}$ & $\begin{array}{c}\text { Direct-fired } \\
\text { Mean } \pm \text { std. dev. }\end{array}$ & Reduction \\
\hline NNN & $0.08 \pm 0.05$ & $1.16 \pm 0.98$ & $\mathbf{9 3 \%}$ \\
NAT & $0.13 \pm 0.10$ & $1.64 \pm 0.90$ & $\mathbf{9 2 \%}$ \\
NNK & $0.09 \pm 0.08$ & $1.95 \pm 1.17$ & $\mathbf{9 5 \%}$ \\
Total TSNA & $0.30 \pm 0.20$ & $4.75 \pm 2.79$ & $\mathbf{9 4 \%}$ \\
\hline
\end{tabular}

a Samples found to be below the limit of quantification were assigned a value of $0.07 \mathrm{ppm}$ (one-half the LOQ).

lation systems similar to those described earlier. Barn conversions for the year 2000 did not include the curing computers. Also, if possible, existing intake dampers were used or a single manually operated damper was installed.

A total of 2094 tobacco samples was taken throughout the curing season from the converted heat-exchange barns and compared to 110 similarly collected direct-fired samples. The data, summarized in Table 5 , show a $94 \%$ reduction in total TSNA levels in tobacco from the heat-exchange barns compared to tobacco from direct-fired barns. NNN, NAT, and NNK were reduced $93 \%, 92 \%$, and $95 \%$, respectively. Of the tobacco samples taken from heat-exchange curing barns, $1160(55 \%)$ were BLQ, whereas no samples from direct-fired barns were BLQ. For the purpose of statistical analysis, BLQ samples were assigned a level of $0.07 \mathrm{ppm}$ (one-half the level of quantification).

BOYETTE and HAMM (27) in independent experiments conducted during the 2000 season reported that heatexchange curing reduced the TSNA levels in cured leaf by more than $93 \%$. Concluding that while "other factors may have a very minor effect on TSNA levels in cured leaf, the single greatest reduction in levels occurred when the products of curing fuel combustion were kept from the curing air".

\section{CONCLUSION}

Data presented in this paper strongly support the contention that TSNA formation can occur by reaction of oxides of 
nitrogen $\left(\mathrm{NO}_{\mathrm{x}}\right)$ with tobacco alkaloids, and that direct-fired curing provides the combustion by-products, namely $\mathrm{NO}_{\mathrm{x}}$, that contribute significantly to the formation of TSNA during the flue-curing of tobacco. Direct-fired curing was shown to be the primary source of TSNA formation in fluecured tobacco, significantly overshadowing any microbialmediated mechanisms. Heat-exchange curing practices, including those in existence for several decades, were shown to significantly reduce TSNA levels in flue-cured tobacco. Also important, conversion to heat-exchange curing does not alter the integrity, quality, and smoking characteristics of flue-cured tobacco since the basis of the flue-curing process is not altered by the change in burner configuration.

Furthermore, work at RJR has shown no significant TSNA formation or accumulation during proper storage or aging of flue-cured tobacco used for cigarette manufacture. Similar work by ANDERSEN and BURTON on air-cured tobacco supports this finding $(28,29)$. Consequently, TSNA reductions accomplished through heat-exchange curing of Virginia tobacco are not compromised by proper storage and aging prior to cigarette manufacture.

\section{REFERENCES}

1. Druckrey, H. and R. Preussmann: The formation of carcinogenic nitrosamines in tobacco; Die Naturwissenschaften 49 (1962) 498-499.

2. Witschi, H., I. Espiritu, R.R. Maronpot, K.E.Pinkerton, and A.D. Jones: The carcinogenic potential of the gas phase of environmental tobacco smoke; Carcinogenesis 18 (1997) 2035-2042.

3. Brown, B.G., C.G. Chang, P.H. Ayres, C.K. Lee, and D.J. Doolittle: The effect of cotinine or cigarette smoke co-administration on the formation of $O-6$-methylguanine adducts in the lung and liver of $\mathrm{A} / \mathrm{J}$ mice treated with 4-(methylnitrosamino)-1-(3-pyridyl)-1butanone (NNK); Toxicol. Sci. 47 (1999) 33-39.

4. Finch, G.L., K.J. Nikula, S.A. Belinsky, E.B. Barr, G.D. Stoner, and J.F. Lechner: Failure of cigarette smoke to induce or promote lung cancer in the A/J mouse; Cancer Lett. 99 (1996) 161-167.

5. Doolittle, D.J., E. Richter, A.R. Tricker, and B.G. Brown: The effect of cigarette smoke on the metabolism of the tobacco-specific nitrosamine 4-(methylnitrosamino)-1-(3-pyridyl)-1-butanone (NNK) in the A/J mouse; Toxicol. Sci. 48 (1999) 236.

6. Brown, B.G., A.J.Borschke, and D.J. Doolittle: An analysis of the role of tobacco-specific nitrosamines in the carcinogenicity of tobacco smoke; Nonlinearity Biol. Toxicol. Med. 1 (2003) 179-198.

7. Hecht, S.S.: Biochemistry, biology, and carcinogenicity of tobacco-specific $N$-nitrosamines; Chem. Res. Toxicol. 11 (1998) 559-603.

8. Brunnemann, K.D. and D. Hoffmann: Analytical studies on $N$-nitrosamines in tobacco and tobacco smoke; Rec. Adv. Tob. Sci. 17 (1991) 71-112.

9. Baker, R.R.: Smoke chemistry; in: Tobacco: Production, chemistry and technology, edited by D.L. Davis and M.T. Nielsen, Blackwell Science, Malden, MA, 1999, pp. 398-439.
10. Tso, T.C.: Organic metabolism - Alkaloids; in: Production, physiology, and biochemistry of tobacco plant, Ideals, Inc., Beltsville, MD, 1990, pp. 427-486.

11. Wiernik, A., A. Christakopoulos, L. Johansson, and I. Wahlberg: Effect of air-curing on chemical composition of tobacco; Rec. Adv. Tob. Sci. 21 (1995) 39-80.

12. Burton, H.R., L.P. Bush, and J.L. Hamilton: Effect of curing on the chemical composition of burley tobacco; Rec. Adv. Tob. Sci. 17 (1983) 71-112.

13. Wynder, E.L. and D. Hoffmann: Correspondence Cigarette smoking and the histopathology of lung cancer; J. Nat. Cancer Inst. 90 (1998) 1486-1487.

14. Hoffmann, D. and I. Hoffmann: The changing cigarette, 1950-1995; J. Toxicol. Environ. Health 50 (1997) 307-364.

15. Hecht, S.S. and D. Hoffmann: The relevance of tobacco-specific nitrosamines to human cancer; Cancer Surveys 8 (1990) 273-294.

16. Hoffmann, D., K.D. Brunnemann, B. Prokopczyk, and M.V.Djordjevic: Tobacco-specific $N$-nitrosamines and Areca-derived $N$-nitrosamines: Chemistry, biochemistry, carcinogenicity, and relevance to humans; J. Toxicol. Environ. Health 41 (1994) 1-52.

17. Burton, H.R., G.H. Childs, Jr., R.A. Andersen, and P.D. Fleming: Changes in chemical composition of burley tobacco during senescence and curing. 3. Tobacco-specific nitrosamines; J. Agric. Food Chem. 37 (1989) 426-430.

18. Hoffmann, D., S.S. Hecht, R.M. Ornaf, E.L. Wynder, and T.C. Tso: Chemical studies on tobacco smoke. XLII. Nitrosonornicotine: Presence in tobacco, formation, and carcinogenicity; IARC Sci. Public. 14 (1976) 307-320.

19. Parsons, L.L., M.S. Smith, J.L. Hamilton, and C.T. MacKown: Nitrate reduction during curing and processing of burley tobacco; Tob. Sci. 30 (1986) 100-103.

20. Brunnemann, K.D., S.S. Hecht, and D. Hoffmann: $N$ Nitrosamine: Environmental occurrence, in-vivo formation and metabolism; J. Toxicol.-Clin. Toxicol. 19(6\&7) (1982-83) 661-688.

21. Scanlan, R.A., J.F. Barbour, F.W. Bodyfelt, and L.M. Libbey: $N$-Nitrosodimethylamine in nonfat dry milk; ACS Symposium Series: Nitrosamines and related $N$ nitroso compounds, Ch. 3,1994, pp. 34-41.

22. Startin, J.R.: $N$-nitroso compounds in foods and drinks: Eur. J. Cancer Prev. 5 (1996) 39.

23. Peele, D.M., D.A. Danehower, and G.D. Goins: Chemical and biochemical changes during flue-curing; Rec. Adv. Tob. Sci. 21 (1995) 82-133.

24. Emission factor documentation for AP-42, Section 1.5, Liquified petroleum gas combustion; 5th Edition, United States Environmental Protection Agency, Research Triangle Park, NC, 1995.

25. Risner, C.H. and F.N. Wendelboe: Quantification of tobacco-specific nitrosamines in tobacco; Tob. Sci. 38 (1994) 1-6.

26. Tso, T.C.: Maturity, harvesting, and curing; in: Production, physiology, and biochemistry of the tobacco plant, Ideals, Inc., Beltsville, MD, 1990, pp.105-124.

27. Boyette, M.D. and L.A. Hamm: Results of year 2000 TSNA sampling program in flue-cured tobacco; Rec. Adv. Tob. Sci. 27 (2001) 17-22. 
28. Andersen, R.A., P.D. Fleming, H.R. Burton, T.R. Himliton-Kemp, D.F. Hildebrand, and T.G. Suton: Levels of alkaloids and their derivatives in air- and fire-cured KY171 dark tobacco during prolonged storage: Effects of temperature and moisture; Tob. Sci. 34 (1990) 50-56.

29. Burton, H.R., L.P. Bush, and M.V. Djordjevic: Influence of temperature and humidity on the accumulation of tobacco-specific nitrosamines in stored burley tobacco; J. Agric. Food Chem. 37 (1989) 1372-1377.
Address for correspondence

Timothy B. Nestor

Research \& Development

R.J. Reynolds Tobacco Company,

Bowman Gray Technical Center,

Winston-Salem, NC, 27102,

USA

Email: nestort@rjrt.com 